\title{
International Standards: Past Free Trade Agreements and the Prospects in the Transatlantic Trade and Investment Partnership
}

\author{
Leif Johan Eliasson \\ Department of Political Science, \\ East Stroudsburg University \\ 200 Prospect Street, \\ East Stroudsburg, PA 18301, USA \\ E-mail: jeliasson@po-box.esu.edu
}

\begin{abstract}
The Transatlantic Trade and Investment Partnership represents a strategic vision of transatlantic relations, including job creation, global leadership, and establishing high international standards. This paper discusses how three recent bi-lateral and regional agreements, along with positions adopted in transatlantic negotiations, convey respective side's acceptable parameters, and how international standards are emerging from and disseminated through agreements involving the European Union and the United States.
\end{abstract}

Keywords:domestic preferences, investments, regulations, standards, transatlantic trade

\section{Introduction}

In 2013 the European Union (EU) and the United States (US) began negotiations on the largest trade and/or investment agreement ever attempted, the Transatlantic Trade and Investment Partnership (TTIP). While tariffs levels are generally low, certain goods such as shoes, automobiles, and food still carry high tariffs across the Atlantic, and their removal or reduction is part of the negotiations. However, various non-tariff barriers (NTBs), which directly or indirectly restrict foreign competition by either banning a foreign presence (denying market access), 
or making it very expensive to compete with domestic producers, constitute greater, and more costly, obstacles for businesses and consumers. ${ }^{1}$

Numerous studies assess the different economic benefits from various levels of reduced or eliminated tariffs and NTBs. On average, removing all tariffs along with half of all NTBs, is estimated to boost EU and US GDP by 0.4 to 0.8 per cent annually (the majority from removing NTBs); the economic benefits to other EU and US trading partners are estimated at 100 billion euros annually (EC, 2013a, p. 11).

More than removing bilateral barriers and promoting regulatory coherence, TTIP represents a strategic vision of transatlantic relations, including job creation, global leadership, and establishing high international standards (cf. Barnier, 2014). Given the size of the transatlantic relationship (700 billion euros in annual bilateral trade, 44 per cent of global GDP, and 60 per cent of foreign investment stock, see EC, 2014a), and that the EU and US are the largest markets for most exporters, agreed standards will become globally dominant. The largest, most complex agreement of its kind deserves examination and analyses from numerous perspectives before, during, and after negotiations end. As well as assessing emerging international standards, this paper can be used as part of a post-hoc evaluation of TTIP negotiations: where, how, and why the results mimicked, expanded on, or diverged from the three previous agreements.

This paper discusses how international standards are emerging from bilateral and regional trade agreements by looking at three recent agreements involving the EU and the US (Republic of Korea-EU, KOREU; Republic of Korea-US, KORUS; Canada-EU, CETA), and the positions adopted and proposals made in TTIP. ${ }^{2}$ These bilateral FTAs provide an indication of the respective side's acceptable parameters, and a TTIP modelled on and expanding beyond the three agreements would create standards applicable to 880 million people in four countries, on three continents, representing over 55 per cent of global GDP. After discussing regulations and rules, the focus turns to progress in select sectors, with comparisons to previous FTAs. The third section looks at general effects on other third countries, especially China.

1 The author had numerous personal discussions with EU and US negotiators, stakeholders, and public officials regarding TTIP in 2012, 2013, and 2014.

2 The text of CETA was leaked in August 2014; ratification is expected by 2016. 


\section{Regulations, rules, standards}

Ahearne et al. (2006) estimate that the EU and the US together account for 80 per cent of global regulations and rules; if the two could harmonize, or make compatible, a majority of these, it would integrate the two economies, while ensuring that most other countries adopt the same standards in order to access the large EU and US markets (Felbermayr, Heid \& Lehwald, 2013, p. 28). There are many ways to remove horizontal and vertical differences between two regulatory systems, including sector-specific coordination or equivalency, mutual recognition, harmonization of product standards, or harmonization of conformity assessments. KOREU, KORUS, and CETA contain commitments to provide national treatments to all goods (similar or substitutable) from the other party; ensure that accreditation and recognition of the other party's conformity assessment bodies are done on the same terms used domestically, and adhere to the stipulations in WTO's Technical Barriers to Trade (TBT) Agreement. There are general commitments on cooperating to remove additional regulatory barriers, increase transparency, enhance mutual understanding of respective systems, align regulations with international standards, and identify and promote standards and technical regulations that respect both sides' laws. Specific safeguard measures are permitted, but cannot conflict with the General Agreement on Tariffs and Trade, Article 24 on market liberalization. Thus safeguards cannot extend beyond two years, nor exceed the lowest tariff of either (a) that which is accorded a third party through existing Most Favorite Nation (MFN) agreements on the same product, or (b) the base rates stipulated in respective treaty's annexes.

KOREU and CETA also contain provisions stating that in service areas not covered by the common European market the EU and Member States (MS) can "maintain or adopt any measures"; and each treaty also includes numerous reservations exempting the country or sector from a treaty's provisions on granting market access to foreign companies, and/or providing a foreign company equal treatment to that of a national. Reservations can apply across one or more of four modes: cross-border supply, consumption abroad, commercial presence, and the presence of natural persons. Countries (including the EU) also list certain commitments as "unbound", enabling maximum freedom to alter market access at any future point. Such flexibility is now a recognized necessity in completing FTAs, meaning there will always be exclusions to "open markets" (cf. UNCTAD, 2006).

Products and services on either side of the Atlantic are generally of equally high quality and safety, and the fastest growing part of transatlantic trade is 
intra-firm. Yet different, regulations and safety practices endure. Cultural and institutional factors make regulatory compatibility or mutual recognition very sensitive in several areas, for example, pharmaceuticals, pesticides, or sanitary and phytosanitary measures (SPS). Many states also object to unlocking certain closed professions (notaries, pharmacies, taxis). Audiovisual services, excluded from KOREU and CETA, were also omitted from the Commission's TTIP negotiating mandate following French objections. On the American side, the 1920 Jones Act, which bans foreign shipping between American ports, is considered a "sacred cow" by trade unions and Democrats, and was excluded from NAFTA and KORUS. ${ }^{3}$ The EU and the US also have fragmented markets in services. EU insurance companies must seek business approval in all 50 American states; the same applies to most other professional services across Europe and the US. Some 90 per cent of the EU public procurement market, worth 352 billion euros, is open to non-EU companies; in the US it is only 32 per cent (by comparison, no Chinese and Indian government contracts are open). Representatives from many states are part of the 600-plus American advisers with continuous access to TTIP proposals, but American states already opened more sectors to foreign bidders in 2012, through the WTO's Plurilateral Agreement on Government Procurement, and so are reluctant to expand further. The US federal government also lacks legal authority to compel changes in state procurement policies, thus making one of Europe's key goals with TTIP, greater access and national treatment at all administrative levels of government, very difficult. However, Canada (also federal) engaged its provinces and agreed to expand market access beyond NAFTA and WTO agreements, quadrupling the acquisition level under which EU companies' takeover bids are treated equivalent to domestic bids (to 1.5 billion Canadian dollars, CETA, ch. XX), thus offering a potential model for TTIP. As a result of MFN clauses in Canada's existing FTAs, the same thresholds will also apply to the US, Mexico, and Korea upon ratification of CETA.

Even staunch free-trade advocates recognize that not all differences can or should be eliminated. Regulations often reflect genuinely different constituent preferences and strategies, serving desired public and social objectives, for example, on health or financial stability. Still, many regulatory differences stem not from divergent preferences and public policy choices, but rather from being devised independently, from a lack of transatlantic coordination. Notwithstanding many joint statements on the desire to see greater transatlantic coordination when writing new regulations, current semi-annual informal transatlantic legislative

3 The 'Jones Act' includes the Merchant Marine Act [1920], 46 App. U.S.C. § 883; the Passenger Vessel Act, 46 App. U.S.C. $\S \S 289,292$, and 316; and 46 U.S.C. § 12108. 
exchanges, and continuous inter-agency dialogues across the Atlantic, neither transatlantic partner assesses the effects of proposals on transatlantic trade or business activities. The Office of Information and Regulatory Affairs studies the impact of US legislation; the Commission assesses (most) EU legislation. Annual compliance costs with American federal laws and EU level regulations are an estimated 50 billion euros and 96 billion euros, respectively (Dudley \& Warren, 2012). Yet many areas have particularly strong potential for some form of coordination or mutual recognition. One study found that a Transatlantic Regulatory Impact Assessment on product safety regulations applied on both sides of the Atlantic would improve real American and European income by 0.05 to 0.1 per cent by cutting compliance costs for business (Morrall, 2011, pp. 7, 32). The Commission proposed a permanent institutional mechanism to continuously ensure "efficient, cost-effective, and more compatible regulations for goods and services, including early consultations on significant regulations, use of impact assessments, periodic review of existing regulatory measures, and application of good regulatory practices" (EC, 2013b); the US prefers to continue with informal dialogue and legislative exchanges.

\subsection{Agriculture and food}

Europeans generally express high trust in scientific research, which guides most public policy (e.g., climate or energy). However, for most Europeans food, and therefore food safety, is a large part of culture; its social value exceeding its nutritional value (cf. Kraus, 2014). If a process has long been thought dangerous, many Europeans may reject scientific studies that find them safe (Pew, 2012; 2014). An example is the Member States' rejection of a genetically modified corn (MON810), a product deemed safe by the European Food Safety Authority; Maize 1507 faces a similar fate. The precautionary principle - the process of proving a negative, of not allowing anything unless scientifically proven not to be harmful-is the guiding approach in setting policy (note: the US also applies this approach, e.g., in pharmaceuticals and homeland security). Citing inconclusive scientific studies on the long-term safety of products such as chlorine-rinsed poultry, hormone treated beef, and various Genetically Modified Organisms (GMOs) proposed for the EU market, the Commission keeps these on its list of "unacceptables" for tariff and quota free entry into the EU (cf., e.g., EFSA, 2008; EU, 2011). The US interprets WTO's Agreement on the Application of Sanitary and Phytosanitary Measures (ASPS) as allowing practices currently rejected in the EU and Korea, and insists the EU apply scientific research as the basis for policy (Congressional Trade Priorities Act of 2014). Yet the "unaccaptables" were left out of KOREU and CETA, and there is no indication of their inclusion in TTIP. 
CETA includes measures to establish equivalencies in each other's inspection and certification systems - a first - while KORUS, KOREU, and CETA all exclude the most "contentious" agricultural products from tariff elimination. The latter is also likely in TTIP, thus solidifying a global norm in trade agreements based on the nebulous standard of "serious domestic interests."

\subsection{Automobiles}

As automotive equals, the EU and the US are partners and competitors. Ten per cent of bilateral trade is in autos and auto parts, and the EU and US combined account for a third of global production and sales; the EU produces more, while the US is the largest market (OICA, 2013). Elimination of all vehicle tariffs (e.g., small trucks and SUVs face American tariffs of 25\%) is assumed a TTIP minimum; with similar levels of safety (accident statistics per capita are nearly identical), divergent standards on things like headlights, windshields, or side impact testing, remain the focus. Business leaders urge transatlantic partners to "act now...making use of first-mover advantage" to create a transatlantic auto market that improves competitiveness and sets global standards (Freund, 2014).

KORUS requires Korea to abolish its tariffs faster and remove more NTBs than the US. American automakers can export 25,000 vehicles to Korea under US safety standards (which is equivalent to a Mutual Recognition Agreement (MRA) since sales from all manufacturers averaged 4,000-5,000 annually in 20012010). Korea agreed to harmonize regulations on 42 items related to vehicle standards, and all US automobiles within 19 per cent of Korean emissions and fuel economy standards are recognized as compliant in Korea through 2015 (ch. 2, sec. A, D, F; ch. 11, 12, 14; Agreed Minutes ..., 2010). Harmonizing standards continuous through the World Forum for Harmonization of Vehicle Regulations (WP.29) within the framework of the United Nations Economic Commission for Europe (UNECE), and all "technical regulations" affecting trade must be based on "available scientific and technical information, related processing technology, or intended end-uses of products." (KORUS, ch. 9, art. 7(2)). The core safety standards in the WP.29 apply in KOREU, and 29 other UNECE regulations will be adopted by Korea by 2016; only tractors, snow mobiles and construction vehicles are excluded (Annex 2-C, art. 1-9). Korea also agreed that remaining differences (not subject to equivalence or harmonization) must be applied without creating market access problems, and all tests carried out in the EU, under EU standards, are accepted in Korea (thus creating equivalence). Rules of origin requirements are set at a minimum of 55 per cent of regional value content (using ex-works method, roughly equivalent to the build-down methods 
used in KORUS); a percentage which also applies to most other manufactured or processed items. In an example of treaty harmonization and convergence it was agreed that when KORUS emission standards (more lax than in KOREU) took effect they became applicable also to KOREU (cf. Annex 2C, ft. 3).

CETA resulted in 17 standards from the WP.29 being recognized by Canada as equivalent to its own, the first time a NAFTA member has done this. There is derogation for seven years for automobiles and trucks with less than 50 per cent non-originating material, following which 60 per cent of the build-down value must originate in the EU or Canada, respectively. However, that figure drops to 30 per cent for the first 100,000 vehicles, far exceeding what either side imports from the other. If TTIP is enacted, American parts will also count as Canadian for the sake of origin (like Canadian beef count as part of America's beef export quota to Europe). With MFN clauses in all agreements, and high CETA quotas, manufacturers could produce the same vehicles for all four markets; with TTIP we could see the first truly global automobile. ${ }^{4}$

\subsection{Investments}

With the world's largest bilateral investment relationship, this section of TTIP is largely meant to set standards that can be applied in negotiations with other countries and regions. To this effect, most of the provisions in a 2012 joint statement on principles guiding investments are slated for inclusion in the TTIP (EC, 2012). Both the EU Commission and the US also insist on some form of Investor-State Dispute Settlement system (ISDS). The 2014 Congressional TPA (sec. 2, § 4), US TTIP negotiators, and the Commission's negotiating mandate all insist that ISDS will not impede government's legislative and regulatory independence, while allowing for legitimate investor claims when discriminated against based on nationality, denied due process, or have company assets expropriated without compensation (cf. Fox, 2014). This remains contested. Ikenson (2014) argues that investments are by nature risky; an ISDS encourages discretionary investments and socializes private risks, while presuming that domestic courts are inadequate to cope with legal challenges. The EU Commission insists that ISDS raises serious concerns, potentially affecting the jurisdiction of Member State courts (EP, 2014). However, a majority of EU Member States want to retain ISDS, and insist it can both safeguard legitimate European public policy objectives and ensure that European investors are adequately protected from American treaty circumvention such as local favoritism, "padded contracts," and "pork-barrel politics" (Keating, 2014; Whittington, 2014). Kleinheisterkamp (2014) finds

4 The most homogenized car, the Ford Fusion, is only $80 \%$ similar across the Atlantic. 
that ISDS cannot compensate for, nor override, weak local laws in America, yet Erixon (2014) finds ISDS necessary for that very reason. Having national courts settle investment disputes means transposing the content of investmentprotection into domestic law; yet, most domestic laws generally treat foreign entities differently than national ones, and states can change relevant laws and regulations to fit a political whim, thus necessitating a treaty-specific dispute system (Erixon, 2014, pp. 4-5).

The Europeans have longstanding experience with ISDS through Bilateral Investment Agreements (BITs), which began in Europe after WWII as investors wanted assurances when investing in former colonies. Member States have signed 1,400 BITs, compared with the mere 48 signed by the US (cf. Lester, 2013). ${ }^{5}$ EU investors also use ISDS more than their US counterparts, especially within the EU, but the state prevails in most cases, both in the EU and globally (UNCTAD, 2014). Recent agreements also contain ISDS. KOREU has an extensive ISDS, with exclusions for certain sectors, ASPS in particular; KORUS is similar. CETA's ISDS applies to most areas, including SPS measures and financial services, and allows, according to leaked 2014 texts, private challenges against regulations lacking mutually recognized prudential character. According to TTIP negotiators, CETA is the model discussed for TTIP.

\section{Other effects on third parties}

While ISDS in TTIP is intended to display a united front in safeguarding investor rights, it is equally important in setting a standard that can be invoked in negotiations with China, Russia, and other countries lacking strong, independent, and transparent legal systems. Neither the US nor the EU are today independently capable of convincing China to open markets, reject protectionism, cease discriminatory practices, and protect intellectual property. A completed TTIP signals Western unity and commitment to an open international system, with increasingly harmonized rules, standards, and practices. Chinese exporters will then have to comply with Western-based standards, while exporters to Chinafrom countries also shipping to the EU and US and adhering to rules and standards set through TTIP — will be so numerous as to constitute a second level of external pressure on the Chinese authorities to accept these provisions; China has previously liberalized according to Western standards (cf. Trigkas, 2014).

5 BITs can remain in force (transitionally) with new EU-level bilateral agreements (EU, 2012). 
The Chinese leadership is increasingly concerned with being sidelined and subjected to standards set by its economic rivals through agreements such as the Transpacific Partnership, TTIP, and Trade in Services Agreement (TSA) (Guoyou \& Wen, 2012; Layne, 2014). During the global financial crisis, China showed willingness to assume some responsibility for international stability, engaging in the G20, refraining from new protectionism, and increasing the float of its currency (Drezner, 2014). In proposing negotiations on separate investment agreements with the EU and the US, China indicated a readiness to use a negative rather than a positive list of sectors open to foreign investors. It also wants to join the TSA. While the EU sees this as a way of engaging China, the US is opposed. It is suspicious of China's intentions in light of its aggressive stance with its neighbors in recent years, and questionable adherence to international agreements, evidenced by WTO dispute panel rulings (see, e.g., WTO, 2014). Ülgen (2014) discusses the benefits of formal third-party consultation on negotiations, for the purpose of ensuring greater cross-national convergence, but both TTIP partners reject any involvement prior to completion. Nevertheless, finding ways to engage others, especially China, will prove necessary to cement commitments to a transparent and rule-based international trade and investments system (Shi, 2013).

Trade diversion from TTIP has also been raised. Schoof, Petersen and Felbermeyer (2013) identify some trade diversion among rich countries stemming from a comprehensive TTIP, but a 2014 World Economic Forum report, using a different methodology, finds very low trade diversification from mega-regional trade deals. The report instead highlights benefits for third countries: as TTIP spurs economic growth in the US and EU this increases consumer purchases of other countries' products, while common transatlantic regulatory approaches reduce costs for exporters and importers - which is crucial as 70 per cent of global trade consists of intermediate goods and services, and capital goods (WEF, 2014; cf. OECD, WTO and World Bank Group, 2014). Other studies on modern multilateral regional agreements show similarly minimum diversion, increased intra-industry and third-party trade, and job creation (cf. Roland-Holst, Reinert \& Shiells, 1994, p. 163; Wolf, 2007, p. 8; Oldenski, 2014). The application of MFN clauses to third countries also offers a means of moderating any potential negative externalities emanating from TTIP. Extending MFN treatment on services to countries willing to abide by the rules and regulations agreed in TTIP also expands common standards and increases global convergence, in effect creating a "WTO plus". 


\section{Conclusion}

Though some conspicuous differences exist, KORUS, KOREU, CETA are sufficiently similar, and contain MFN clauses on most issues, to enable Canada and Korea to relatively easily adopt standards in, or even accede to, TTIP, thus quickly broadening agreed standards to four parties across three continents. Though these agreements are templates for TTIP, it also deserves remembering that in previous negotiations the EU and the US used their size and attractiveness to extract greater concessions from, and reforms in, the other signatories, resulting in (a) longer transition periods with higher retained tariffs on imports during those transitions; (b) greater recognition of their own standards and greater access to the other's markets; (c) exclusion of goods and services they wanted to protect (e.g., domestic shipping in the US and GMOs and audiovisuals in the EU). TTIP requires unprecedented mutual accommodation, where finding overlap in respective actor's range of acceptable outcomes will prove more challenging than anything previously encountered. However, the EU and the US have successfully cooperated elsewhere in establishing standards, for example, through the International Standardization Organization and the International Medical Device Regulatory Forum; 17 medical device standards had been mutually recognized by 2014 , and this sector was also among the first where the EU and US exchanged formal texts for TTIP in May 2014.

Economic benefits and standard setting impacts notwithstanding, policy makers and legislators assess trade and investment agreements by a different metric. Politics, not economics, will decide the fate of TTIP. Like CETA, TTIP will be a mixed agreement (affecting EU and national legislation) requiring ratification in all 28 Member States, and public opposition has grown (Pew, 2014). Ideological convictions, fear, and lack of knowledge of the complexity of foreign affairs and trade intermingle to produce often irreconcilable demands (e.g., specific protectionism at home while opening markets abroad, or opposition to labor standards even when the other country's standards are higher, cf. Deutsche Welle, 2013). Regulatory changes also face resistance from affected authorities and bureaucracies, who for political reasons (power) and self-interest (fear of losing jobs and resources) oppose change. Thus advocates of TTIP will need astute communication and better marketing than for any other previous FTA. 
Leif Johan Eliasson is associate professor of political science at East Stroudsburg University. He is the author of two books, including America's Perceptions of Europe (2010), and several scientific articles and book chapters on transatlantic trade, security, and European integration. From 2011 to 2014 he was chair of the Transatlantic Consortium for European Union Studies and Simulations.

\section{References}

Agreed Minutes... (2010), Agreed Minutes on regulations pertaining to automotive fuel economy and greenhouse gas emissions, added to the Free Trade Agreement Between the United States and the Republic of Korea, 3 December 2010.

Ahearne, A.; Pisani-Ferry, J.; Sapir, A. \& Véron, N. (2006), The EU and the Governance of Globalization, Working Paper, No. 2006/02, Brussels: Bruegel.

Barnier, M. (2014), Strengthening the Transatlantic Partnership Beyond TTIP: A strategic vision for the EU and US, Speech/14/464, European Commission, 12.06.2014.

BCTPA (2014), Bipartisan Congressional Trade Priorities Act of 2014, H.R. 3830, introduced 19 January 2014.

Dudley, S. \&Warren, M. (2012), Regulators Budget Report, Washington DC: Weidenbaum Center on the Economy, Government, and Public Policy.

Drezner, D. (2014), The System Worked: How the World Stopped Another Great Depression, Oxford: Oxford University Press.

Deutsche Welle (2013), 'Transatlantic coalition rejects anti-consumer trade deal,' 13 June 2013.

EC (2012), 'Statement of the European Union and the United States on Shared Principles for International Investment,' European Commission. Retrieved from http://trade. ec.europa.eu/doclib/docs/2012/april/tradoc_149331.pdf [accessed Oct 2014] (2013a), Transatlantic Trade and Investment Partnership: The Economic Analysis Explained, European Commission, Tradoc 151787, September 2013. (2013b), EU-US Transatlantic Trade and Investment Partnership Trade Crosscutting Disciplines and Institutional Provisions, Initial EU position paper, European Commission, July 2013.

— (2014a), European Commission Trade, Countries, United States. Retrieved from http://ec.europa.eu/trade/policy/countries-and-regions/countries/united-states/ [accessed 23 Jul 2014]

(2014b), 'Note for the attention of the Trade Policy Committee,' CETA Consolidated Text, European Commission Directorate General for Trade, Brussels, 5 August 2014. Retrieved from http://www.tagesschau.de/wirtschaft/ceta-dokument-101. pdf [accessed Oct 2014] 
EFSA (2008), 'Scientific Option of the Panel on Biological Hazards on a Request from DG SANCO on the assessment of the possible effect of the four antimicrobial treatment substances on the emergence of antimicrobial resistance,' European Food Safety Agency Journal, vol. 659, pp. 1-26.

EP (2014), 'Commission Hearings,' European Parliament, 20.09.2014. Retrieved from http://www.elections2014.eu/en/new-commission/hearing/20140917HEA64702 [accessed 28 Oct 2014]

EU (2011), Commission Regulation (EU) 619/2011 laying down the methods of sampling and analysis for the official control of feed as regards presence of genetically modified material for which an authorisation procedure is pending or the authorisation of which has expired, Official Journal of the European Union, L 166, 25.06.2011, pp. 9-15.

(2012), Regulation (EU) No. 1219/2012 of the European Parliament and of the Council establishing transitional arrangements for bilateral investment agreements between Member States and third countries, Official Journal of the European Union, L 351, 20.12.2012, pp. 40-46.

Erixon, F. (2014), 'Investor-state disputes have put a spanner in the works for TTIP' European Voice, 19 June 2014.

Erixon, F. \& Bauer, M. (2010), A Transatlantic Agreement: Estimating the Gains from Transatlantic Free Trade in Goods, Occasional Paper 4, Brussels: European Center For International Political Economy.

Felbermayr, G.; Heid, B. \& Lehwald, S. (2013), Transatlantic Trade and Investment Partnership (TTIP): Who benefits from a free trade deal? Global Economic Dynamics Paper, Gütersloh: Bertelsmann Stiftung.

Fox, B. (2014), 'Germany opposes EU-US investor protection scheme,' EUobserver, 15 March 2014.

Freund, C. (2014), Encouraging a Manufacturing Renaissance through the Transatlantic Trade and Investment Partnership. Presentation at the Peterson Institute for International Economics, Washington, DC, 2 May 2014.

FTA (2007), Free Trade Agreement Between the United States of America and the Republic of Korea of 30 June 2007.

- (2011), 'Free trade Agreement between the European Union and its Member States, of the one part, and the Republic of Korea, of the other part, Official Journal of the European Union L127, 14.05.2011, pp. 1-1487.

Guoyou, S. \& Wen, J. Y. (2012), “China's Free Trade Agreement Strategies," The Washington Quarterly, vol. 35, no. 4, pp. 107-119. http://dx.doi.org/10.1080/016 3660X.2012.726425

Ikenson, D. (2014), The Investor-State Dispute Settlement Mechanism: An Examination of Benefits and Costs. Presentation at CATO, Washington DC, 20 May 2014. 
Keating, D. (2014), 'Member states warn Juncker against ISDS concessions,' European Voice, 22 October 2014.

Kraus, D. (2014), Italian and European Business. Presentation at the Peterson Institute for International Economics, Washington DC, 2 May 2014.

Kleinheisterkamp. J. (2014), Is there a Need for Investor-State Arbitration in the Transatlantic Trade and Investment Partnership (TTIP)? LSE Working Papers, London: London School of Economics. http://dx.doi.org/10.2139/ssrn.2410188

Layne, C. (2014), After the Fall, International Politics, U.S. Grand Strategy, and the End of the Pax Americana, New Haven: Yale University Press.

Lester, S. (2013), Liberalization or Litigation? Time to Rethink the International Investment Regime, Policy Analysis, no. 730, Washington, DC: Cato.

Morrall III, J. (2011), Determining Compatible Regulatory Regimes between the U.S. and the EU, Washington DC: United States Chamber of Commerce.

OECD, WTO and World Bank Group (2014), Global Value Chains: Challenges, Opportunities, and Implications for Policy. Report prepared for submission to the G20 Trade Ministers Meeting, Sydney, Australia 19 July 2014.

OICA (2013), International Organization of Motor Vehicle Manufacturers [Homepage] Retrieved from http://www.oica.net/category/production-statistics/ [accessed Oct 2014]

Oldenski, L. (2014), American Manufacturing Growth Since NAFTA, Presentation at the Peterson Institute for International Economics, Washington DC, 17 July 2014.

Pew (2012), The American-Western European Values Gap American Exceptionalism Subsides, Washington, DC: Pew Research Center's Global Attitudes Project. (2014), Support in Principle for U.S.-EU Trade Pact, But Some Americans and Germans Wary of TTIP Details, Washington, DC: Pew Research Center's Global Attitudes Project.

Roland-Holst, D.; Reinert, K. \& Shiells, C. R. (1994), 'NAFTA Liberalization and the Role of Nontariff Barriers,' North American Journal of Economics \& Finance, vol. 5, no. 2, pp. 137-168. http://dx.doi.org/10.1016/1062-9408(94)90002-7

Schoof, U.; Petersen, T. \& Felbermeyer, G. (2013), Who Benefits from a Transatlantic Free Trade Agreement? Policy Brief, no. 4, Gütersloh: Bertelsmann Stiftung.

Shi, Z. (2013), Is the US-EU Trade Pact a Way to Balance China? Brussels: Carnegie Europe. Retrieved from http://carnegietsinghua.org/2013/06/17/is-u.s.-eu-tradepact-way-to-balance-china/gand [accessed 4 Aug 2014]

Thies, A. (2013), International Trade Disputes and EU Liability, Cambridge: Cambridge University Press. http://dx.doi.org/10.1017/CBO9780511842078

Trigkas, V. (2014), 'The Strategic Implications of TAFTA/TTIP: Will it Engage or Contain China?' in D. Cardoso et al. (eds.) The Transatlantic Colossus, Berlin: Berlin Forum on Global Politics, Internet \& Society Collaboratory, pp. 54-59. 
Ülgen, S. (2014), Locked In or Left Out? Transatlantic Trade Beyond Brussels and Washington, Working Paper, Brussels: Carnegie Europe.

UNCTAD (2006), Preserving Flexibility in IIAs: The use of reservations, New York \& Geneva: United Nations Conference on Trade and Development.

- (2014), Recent Developments in Investor-State Dispute Settlement, New York \& Geneva: United Nations Conference on Trade and Development.

WEF (2014), Mega-regional Trade Agreements Game-Changers or Costly Distractions for the World Trading System? Cologne \& Geneva: World Economic Forum.

Whittington, L. (2014), 'Implementing Canada-EU free-trade deal could take another two years,' The Star, 24 April 2014, p. 3.

Wolf, M. (2007), 'A Korean-American strand enters trade's spaghetti bowl,' Financial Times, 3 April 2007.

WTO (2014), China - Anti-dumping and countervailing duties on certain automobiles from the United States, World Trade Organization Dispute Settlement Report WT/ DS440/R. 